1. 除草削隐用上记㤁ける2、3 の添祭

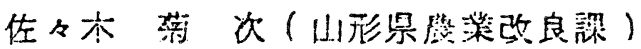

目的：1）桑園雑草アサズキの防除法（AT A，2,4-D+A I A )

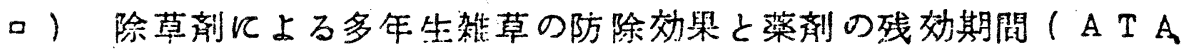
$2,4-D+A T A 、 P C P($ \&)

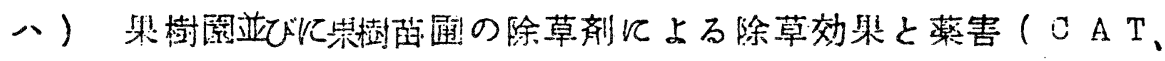
$A T A 、 2,4-D+A T A 、 P C P$ 棌加)

方法：1，10月初旬、高刚案国下草アサズキに放しATA、2,4-D+

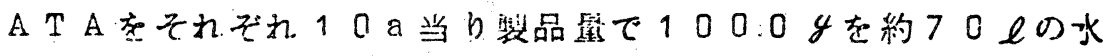
几溶かし、敬布り殺草效然を検討した。

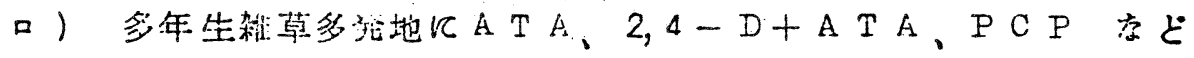

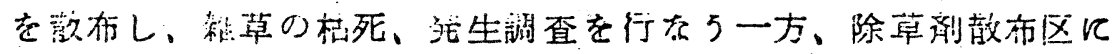

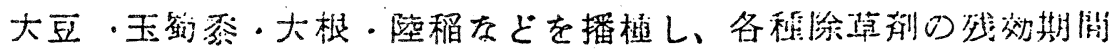

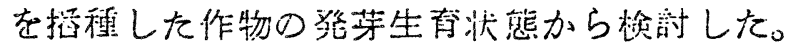

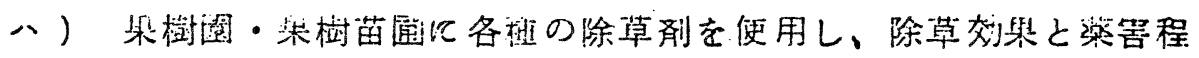

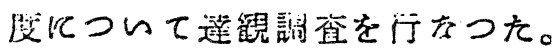

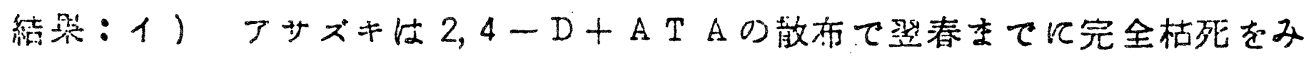
た。A A 红 $7 \sim 8$ 割枯死。

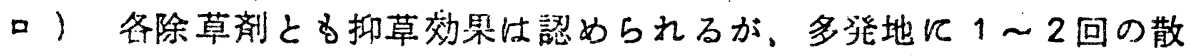

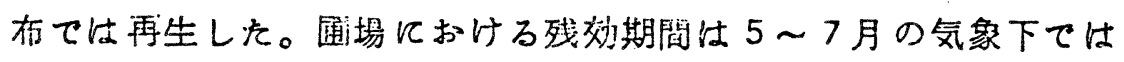
$4 \sim 5$ 罚闔て，後作が実用的几可能と判断された。

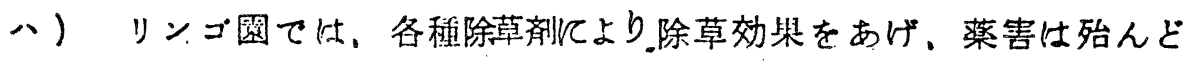

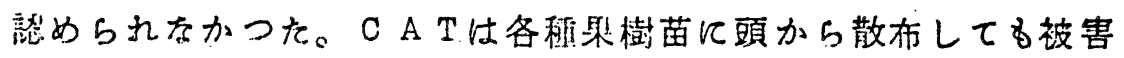
が翟的ら九なかつた。 


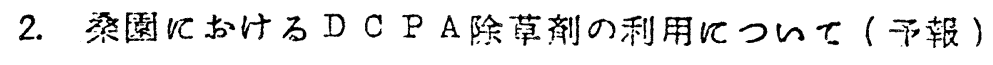

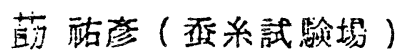

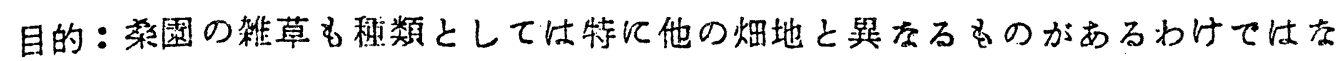

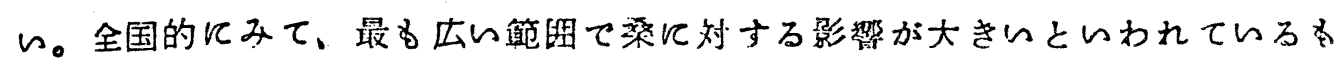

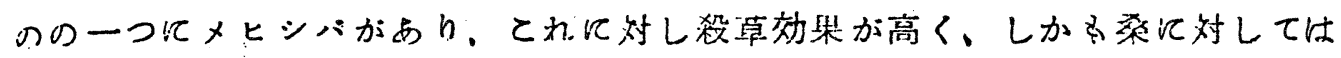

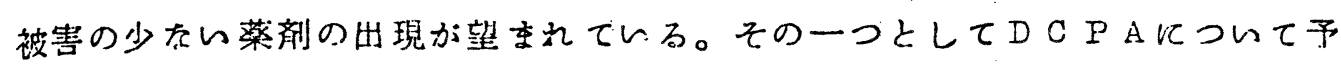
俑的支実駼を行在つた。

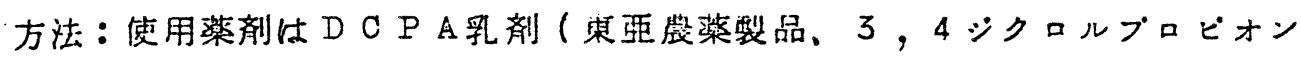
アニリト $25 \%$ 含有)て、その 100 倍液と 200 㹺液散布の 2 区を䛇け、お

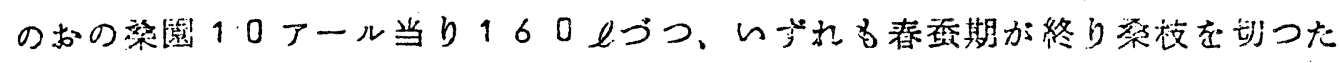

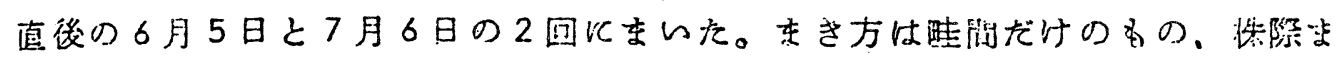

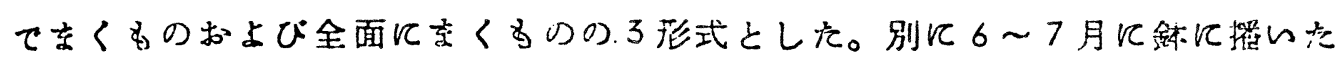

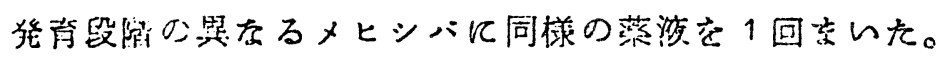

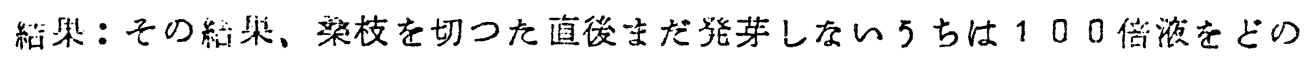

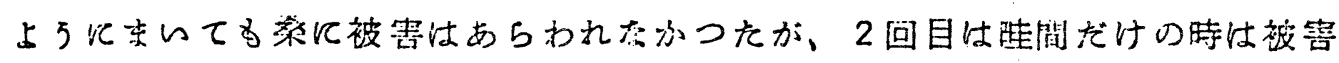

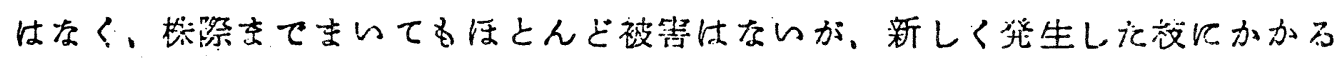

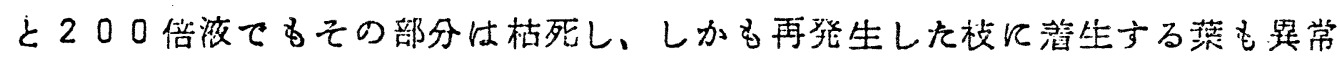
形態を呈し、大きな被害を受汁た。メヒシバについては、散布時期がちがつた

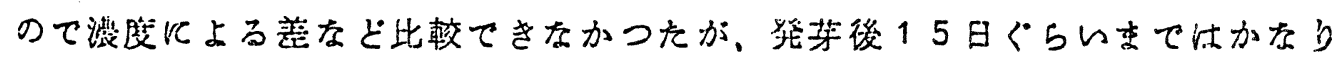

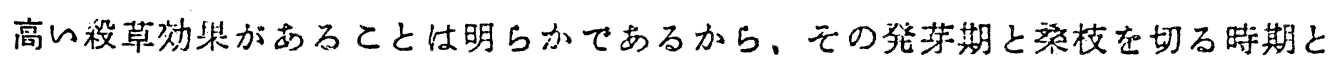

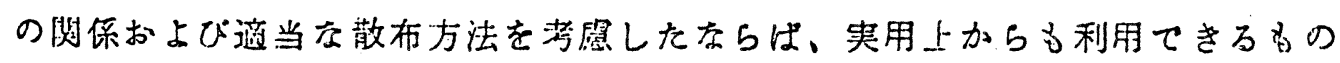
と考えられる。 


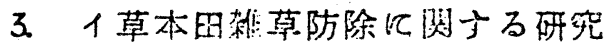

为 1 報 D B N 水和唷に上る稚草防除について

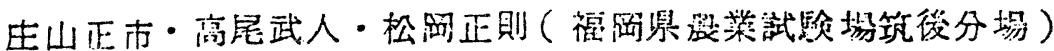

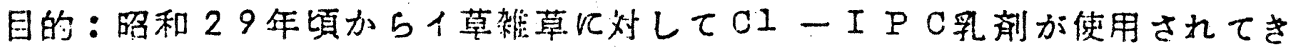
た。イ草雑草に岋マッパ・ミズハコべをの冬雑草、ヒエ・オオアプノメ存

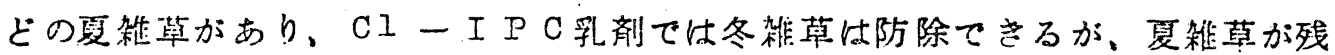

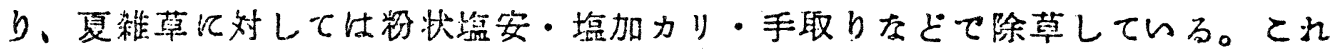
らの方法ては肥料棓画がみだれ、倒伏の原因にるなつている。また、CI－I

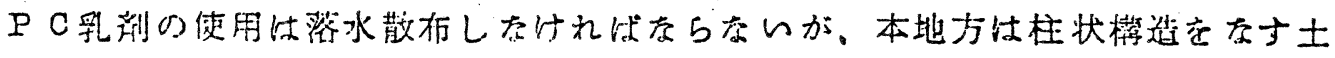

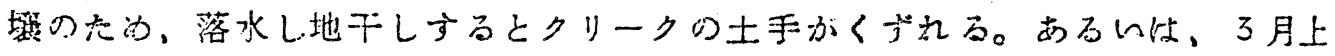

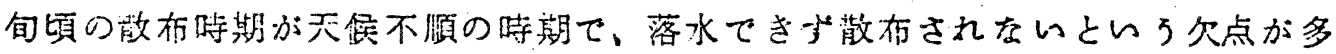

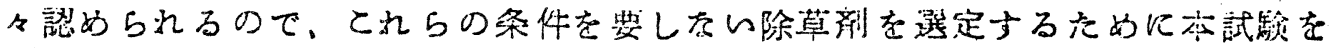
奏旅した。

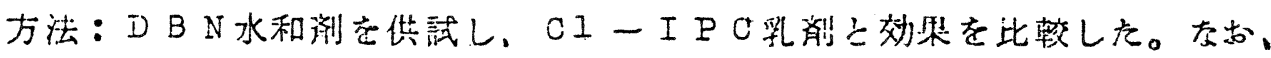

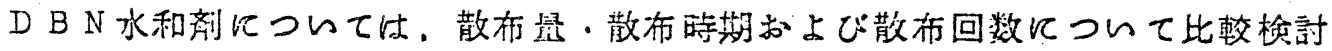
Lた。

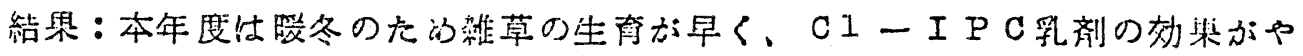

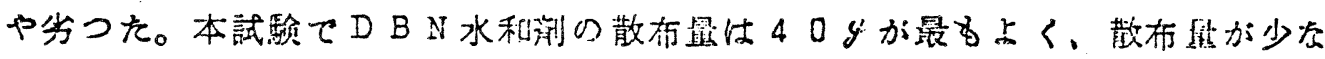

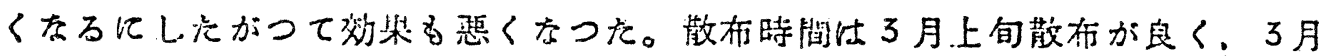

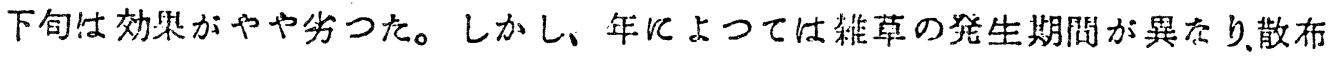

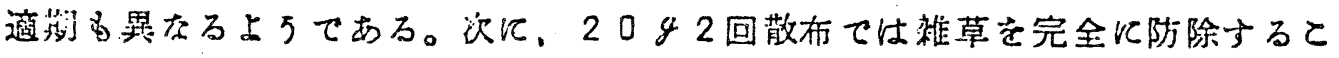
とがさるが、省力的、䌡済的な見知から20g1回散布で十分な除草效果 が㑇的ら九た。 


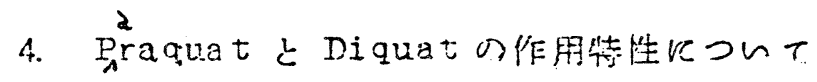

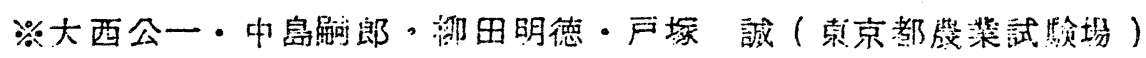

目的：Paraquat お与びDiquatの笑用試路立䇣のための参考凅料として 各程の特性をしらべた。

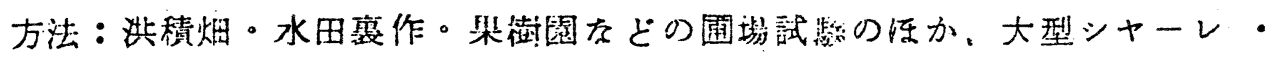

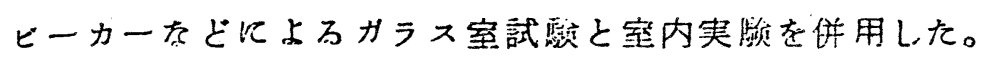

緯箱: Paraquat

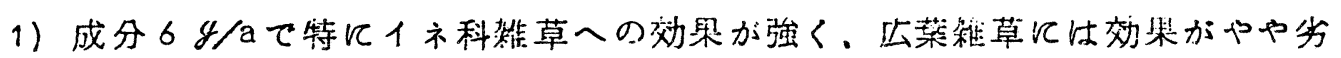
万。

2) 土怔表画ては数時間で消失する。

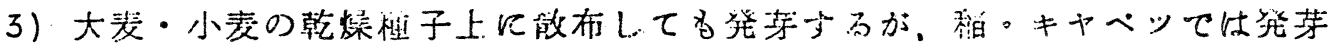
は忙じるが根の伸長が阻害される。

4) N C P ・ D C M U - Prometryne (A-1114) N I P との混用佉 Faraquat の㚳染を浅殺するおそれが的万。

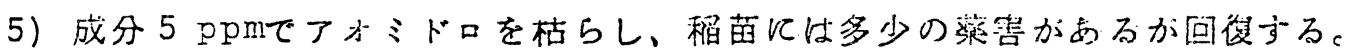

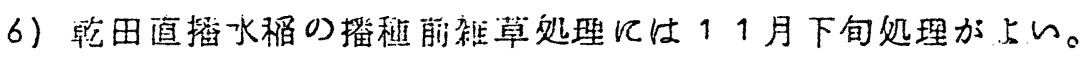
Diquat

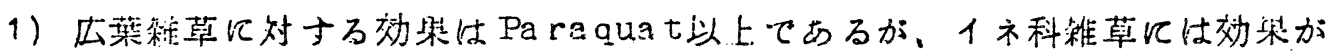
劣る。

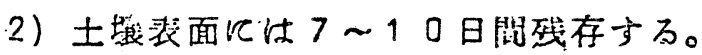

3) 稆・大麦・小麦・キャペッの程子散布すると発芽を阻害する。

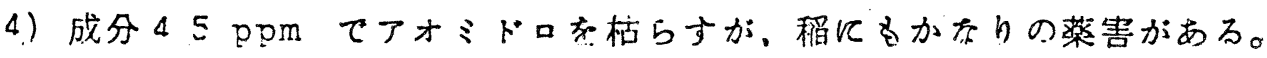
混戍(プリータロン)

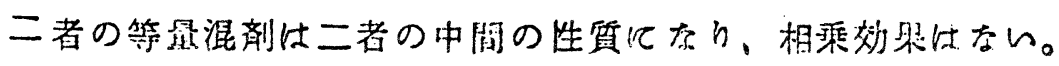




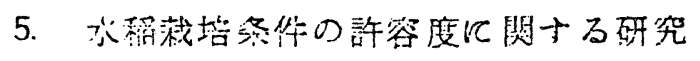

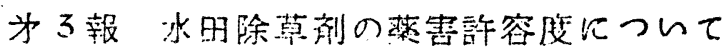

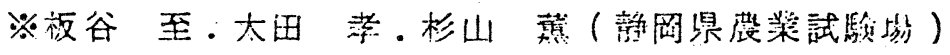

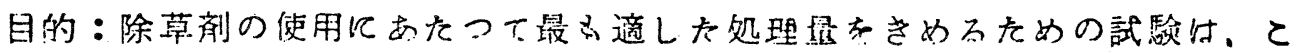

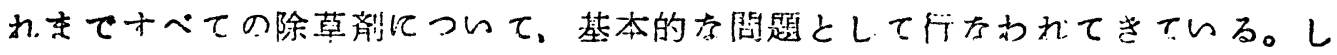

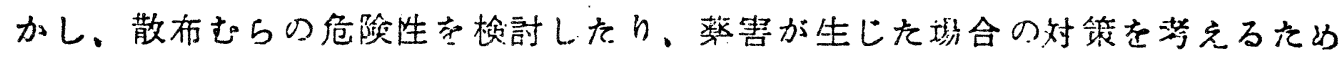

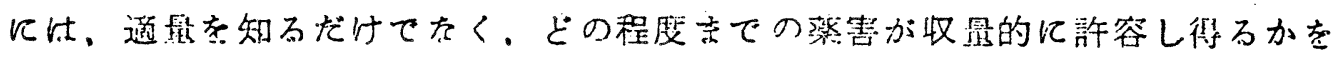
知石必要があ5。

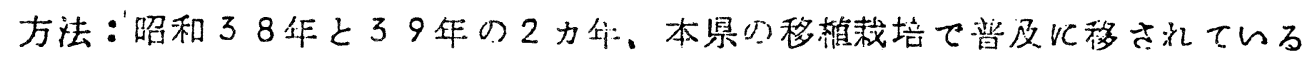

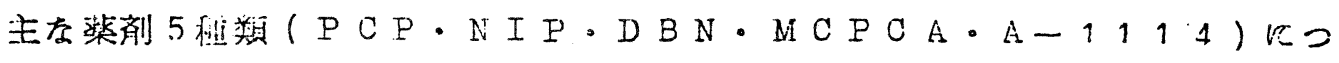

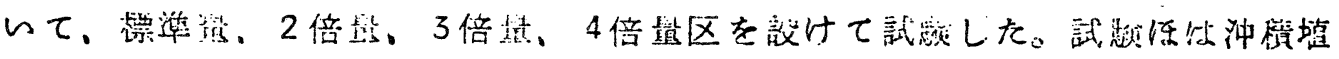
裴土て泟水澡仕小さい。

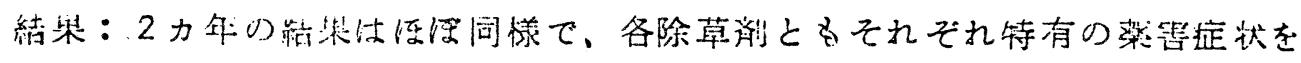

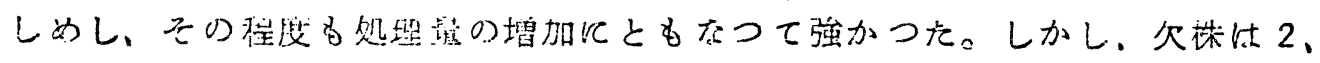

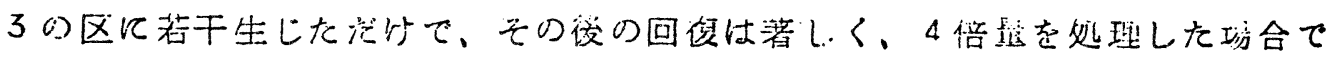

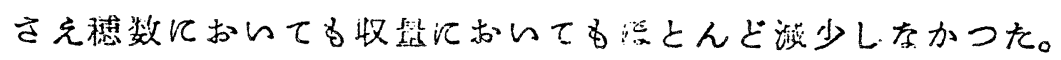

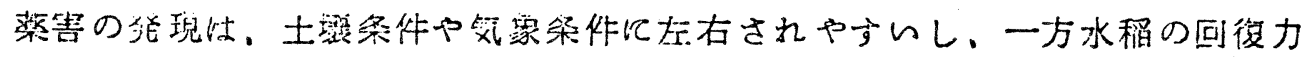

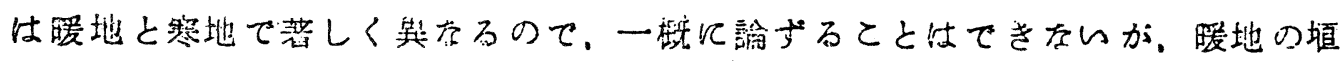

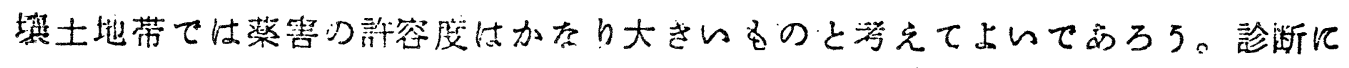

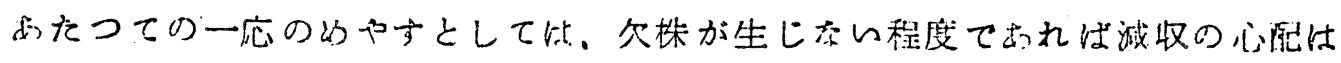
ないタのと判断できるだろら。 


\section{6. 除草剈の流入施用に関方石研究}

为2 䠟 ホルモン棐除草剂の流入施用

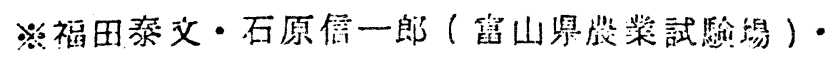

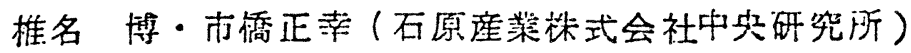

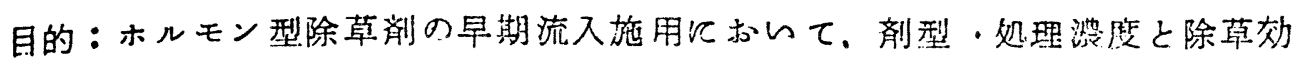

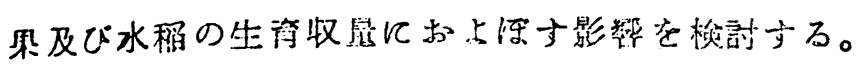

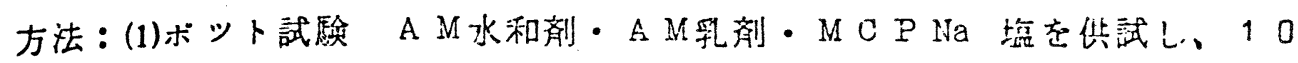

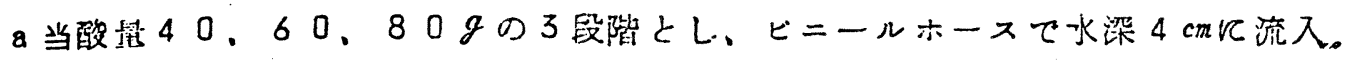
指標雑草としてコナギを1/2000 a ボットル10〜15株生育させた。処理15

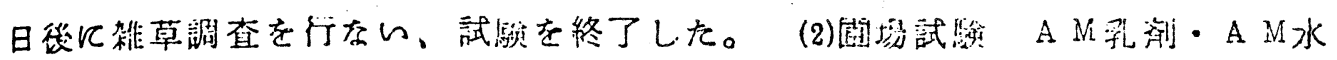

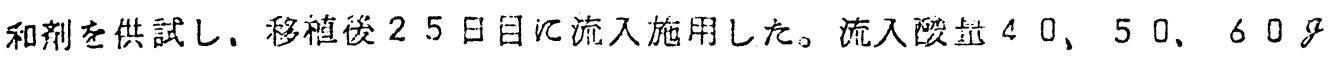

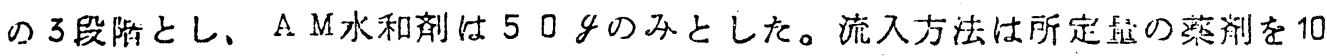

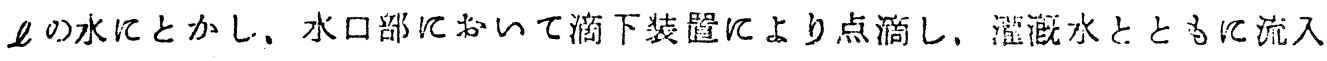
した。終了後1区6力所て田面水を垛取し、緑豆を㭘休として漄度分布を調查 Lた。

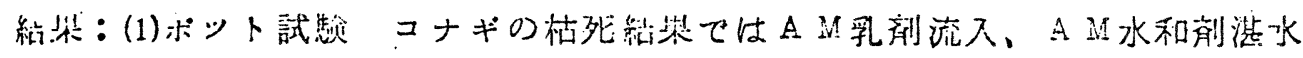

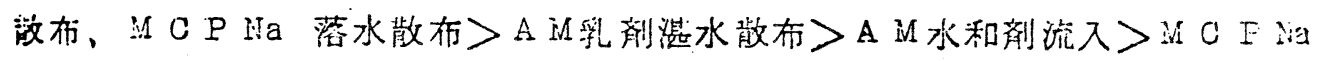

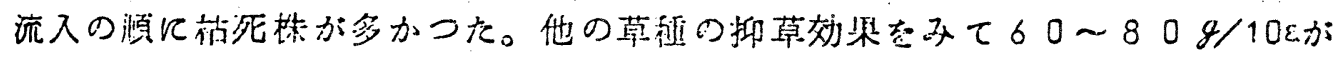
逼当と洘えられる。

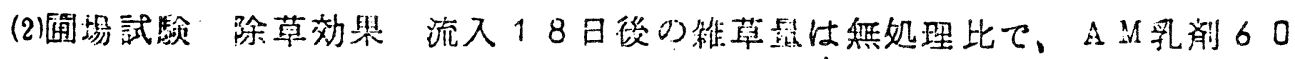

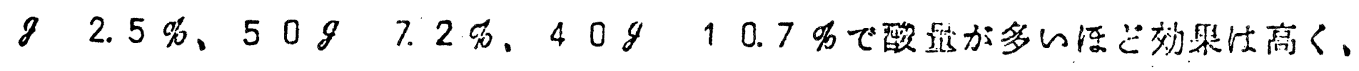

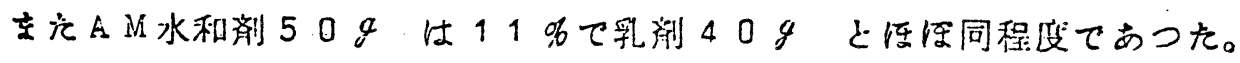

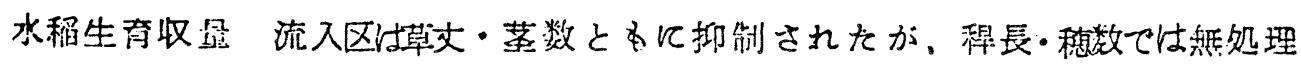

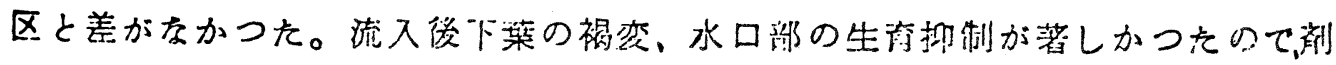

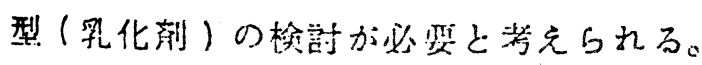




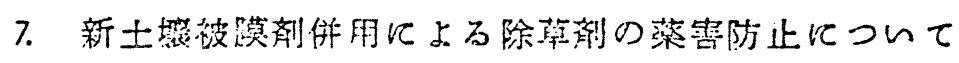

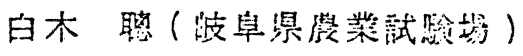

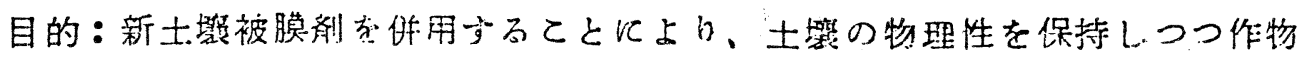

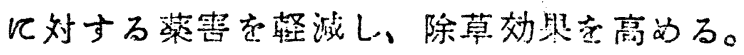

方法：

1) 好焦作物

$$
\text { タマネギ・ダイコン・ホゥレンソウ・ニンシン }
$$

2) 使用除草剂

$$
\text { トレフラン・NIP・OAT・aュックス・P C P }
$$

3) 土妵被膜剂

$$
\text { エルビール・エンキャップ }
$$

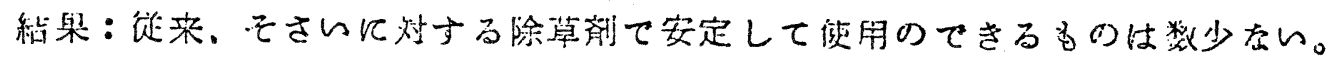

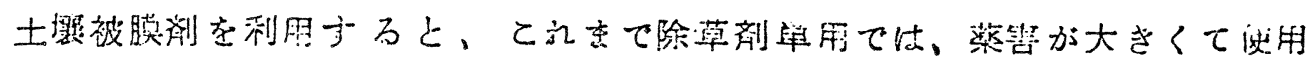

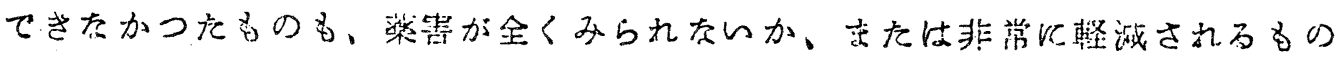

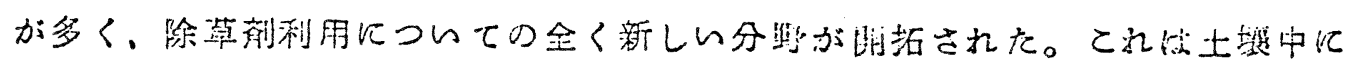

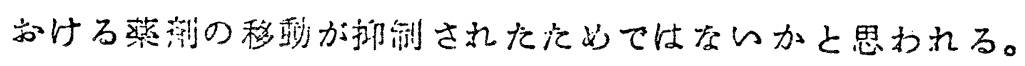

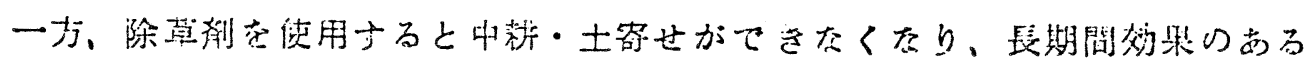

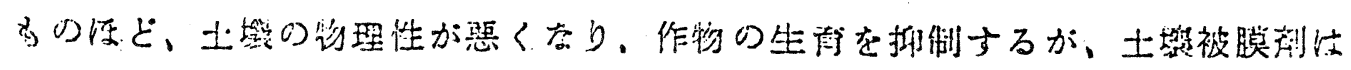

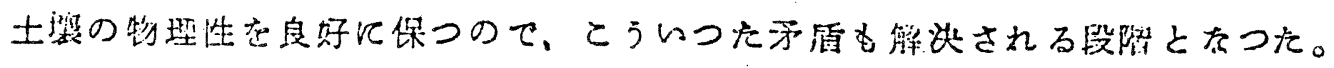




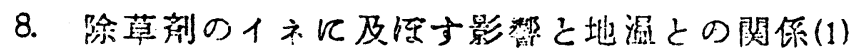

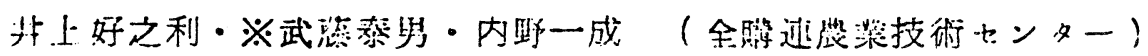

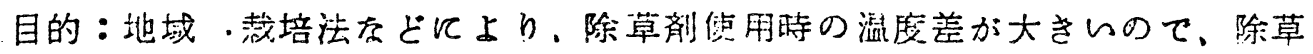

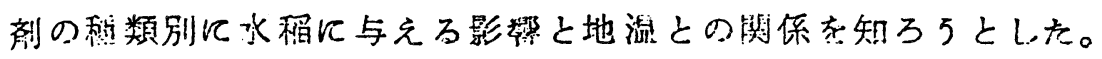

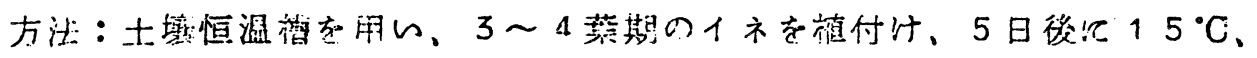

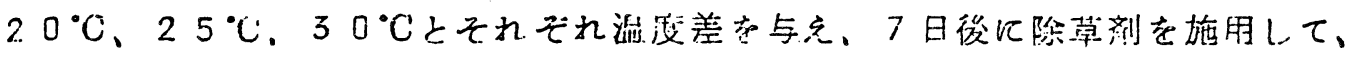

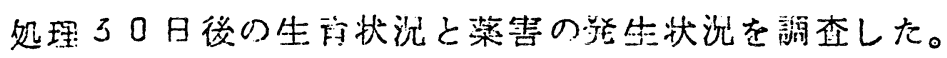

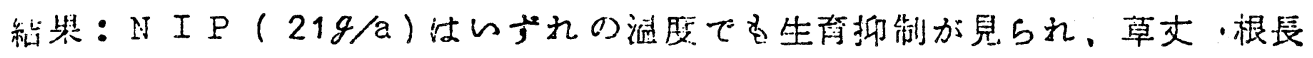

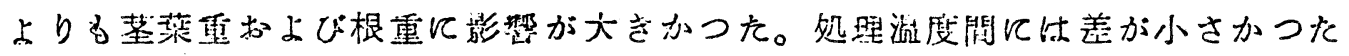

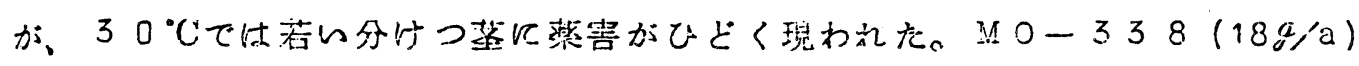

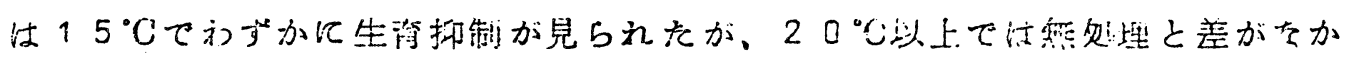

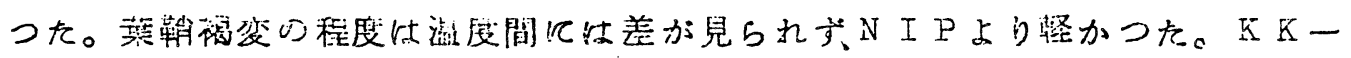

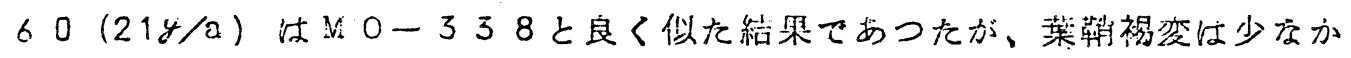

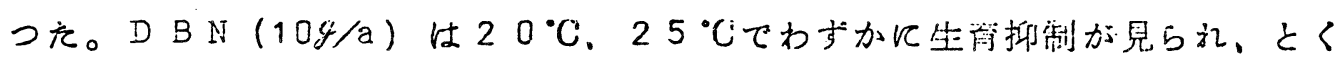

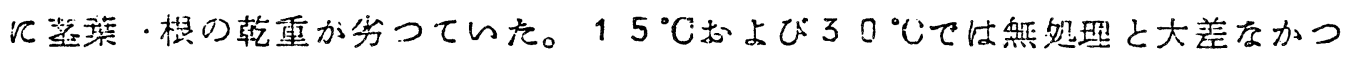

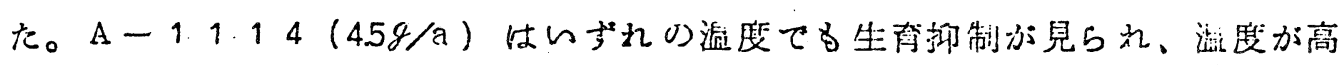

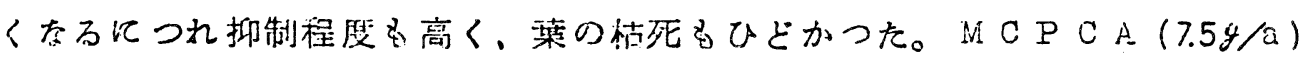

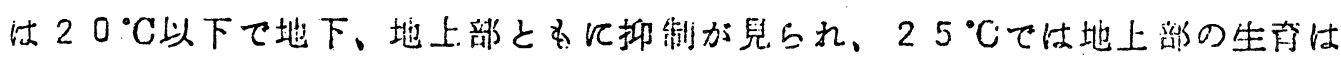

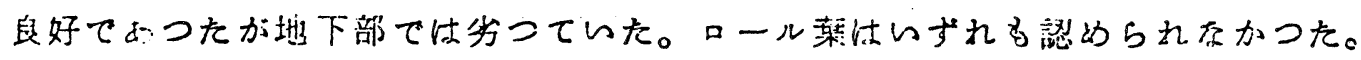
T一M（有機錫、M C P化合物 9g/a) 壮 B C P C A と良く似た傾向を示した。

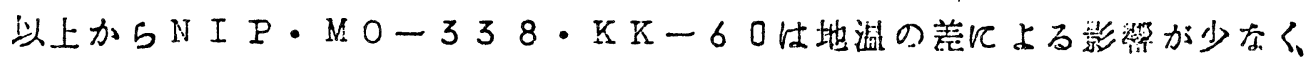

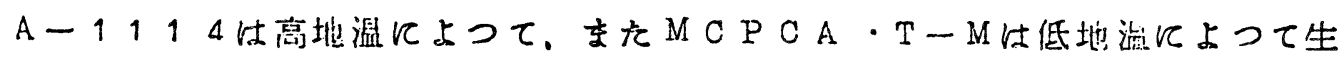
苝抑制が強く古るととを確かめた。 


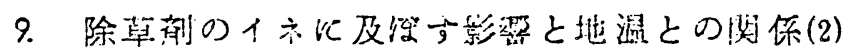

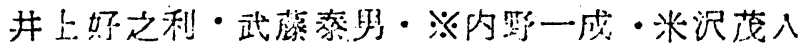

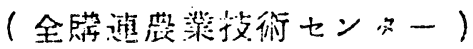

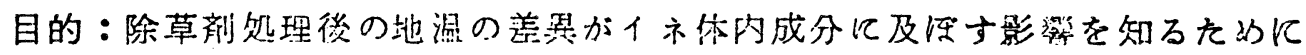
行をつた。

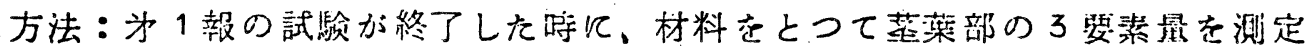

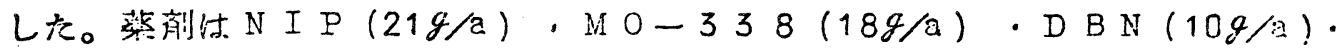
有機錫十 M C P ( T + M:17.5+3.5g/a)てある。

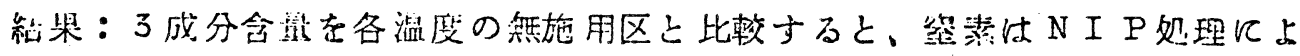

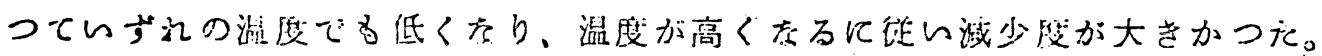

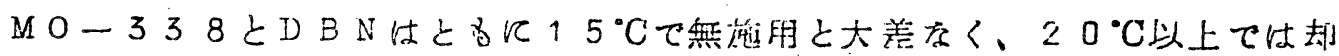

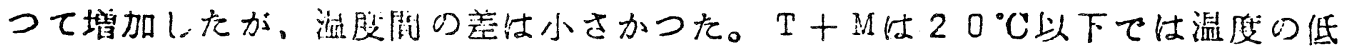

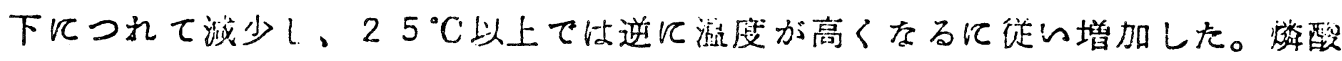

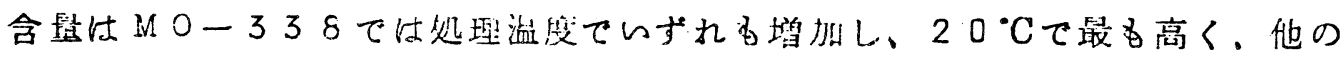

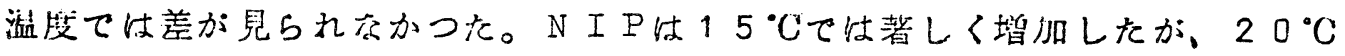

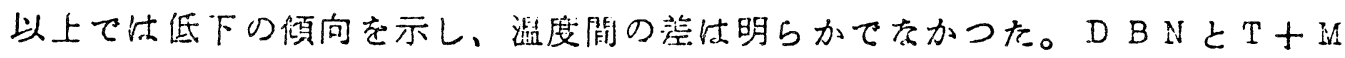

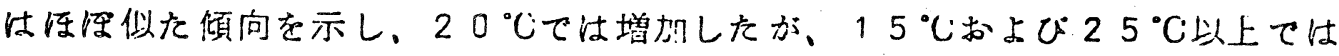

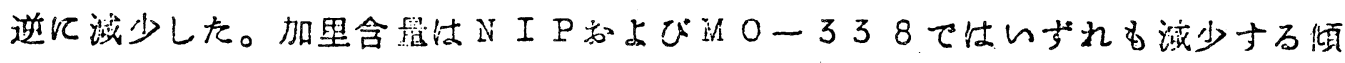
向を示し、MO-3384 $15^{\circ} \mathrm{C} て ゙ 耳^{\prime}$ 減少し $20^{\circ} \mathrm{C}$ 以上ては差がなった。

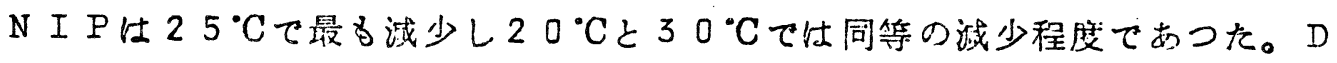

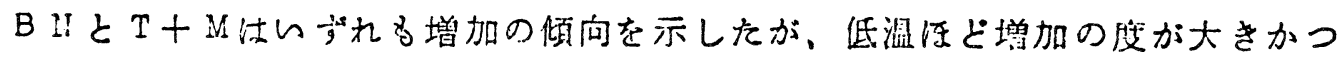
た。 
10. 腙尊剂の作用力の温度に上る愁動

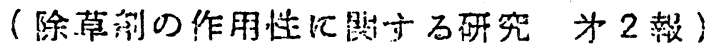

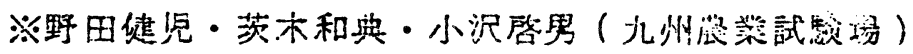

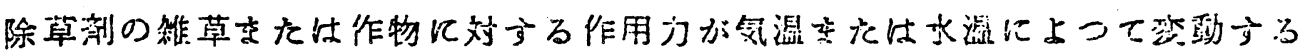

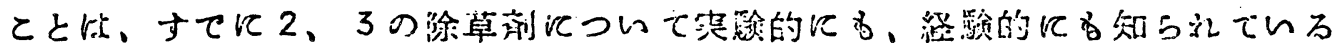

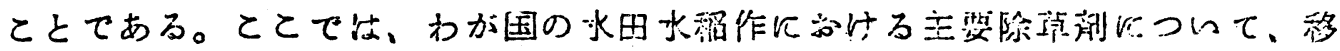

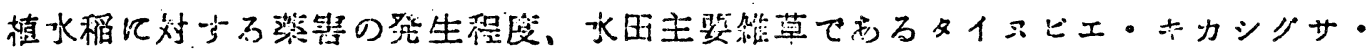

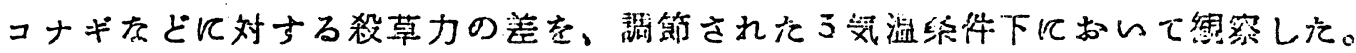

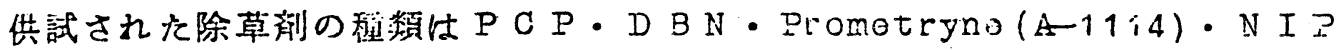

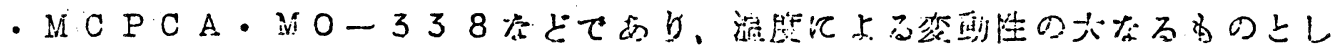

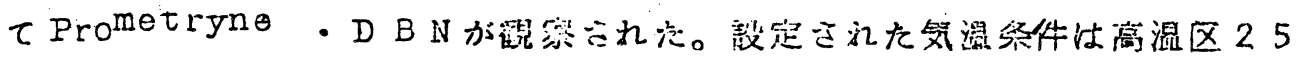

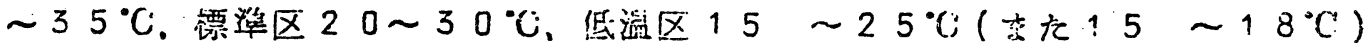
てめつた。 